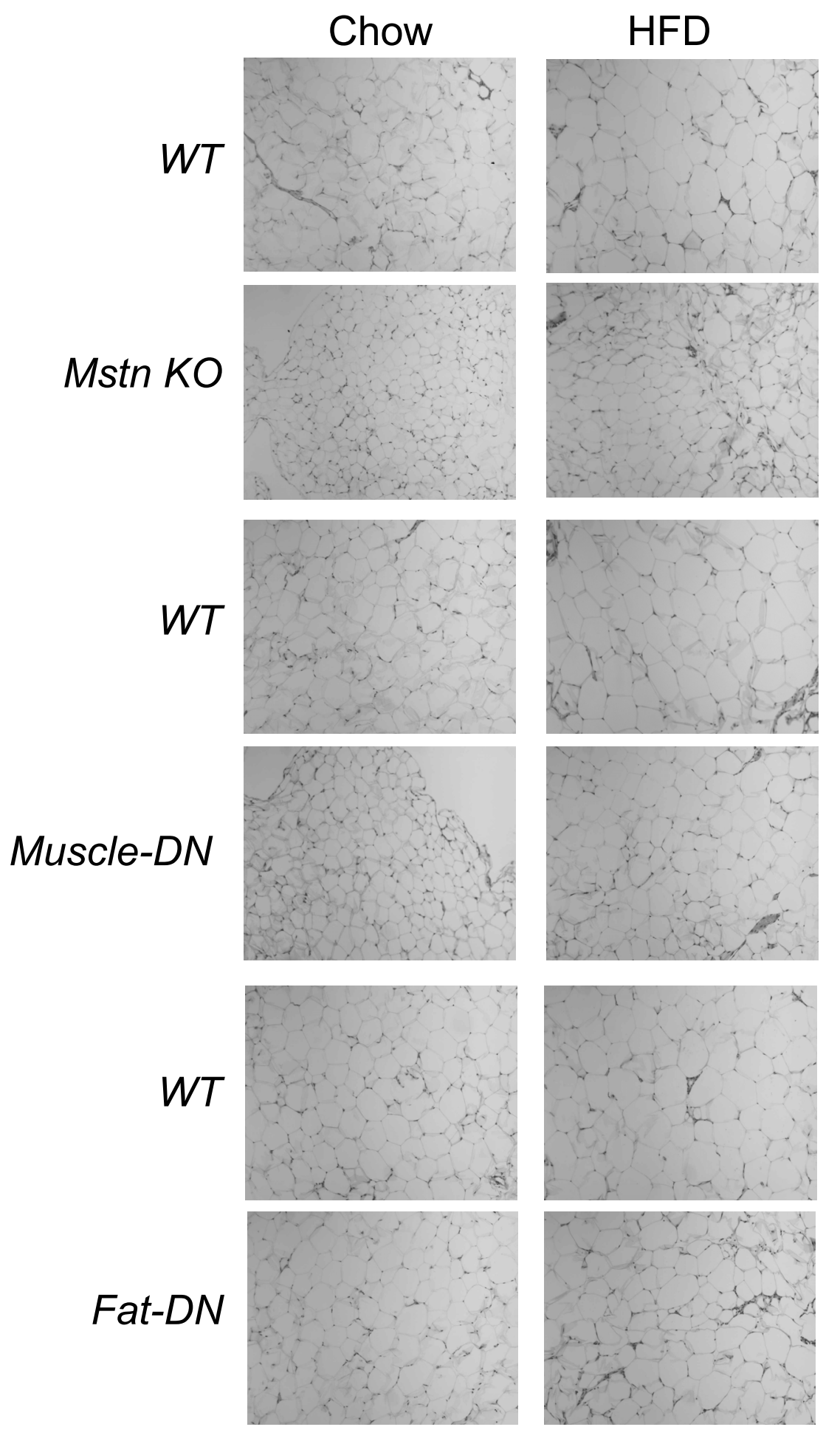

\title{
Figure S2
}

Representative images of $H \& E$ stained gonadal fat pads from mutant mice and control littermates on standard chow or high fat diet (HFD). $\mathrm{Mstn}^{-/-}$and $m u s c l e-D N$ mice, but not fat-DN mice, have smaller adipocytes compared to control mice on both diets. 